\title{
PEMAKAIAN DIKSI DALAM PENULISAN CAPTION MEDIA SOSIAL INSTAGRAM
}

\author{
Amanda Maharani \\ UIN Syarif Hidayatullah Jakarta \\ email: Amanda.maharani17@mhs.uinjkt.ac.id
}

\begin{abstract}
(Title: Usage of Diction in Writing of Social Media Caption Instagram). Communication often goes wrong either misunderstanding or offending. People who have a lot of vocabulary tend to communicate more easily. They know how to use the right diction according to the situation and conditions. The use of social media that is busy lately is widely used to express feelings of happiness, annoyance, disappointment or even anger. This is usually stated in the written status or caption. Indeed there are no provisions in the writing. However, users should be more careful to choose good and correct diction so as not to damage the existing language order. This study used a descriptive qualitative method with 32 PBB class of 5B class of PBSI students. The results obtained are the use of diction: (1) the use of Meaningful Denotation and connotation as many as 17 diction usage, (2) the use of popular words and study words as many as 8 diction usage, (3) the use of jargon, conversation words and slang as many as 16 diction usage, (4) the use of General Words and Special Words are 3 uses of diction, and (5) the use of the words Synonyms and Synchronized are 16 uses of diction. Based on these results it can be concluded that the use of the PBSI Student Class of 5B class 2017 in terms of politeness is quite good and can be accepted by the community
\end{abstract}

Keywords: diction, status, communication, social media

\section{PENDAHULUAN}

Perkembangan teknologi yang semakin maju mulai menggeser cara manusia dalam berkomunikasi. Jika dahulu orang ingin berdiskusi, atau melepas rindu dengan cara bertemu, sekadar menelpon atau berkirim sms. Masa kini kita bisa saling melihat satu sama lain melalui handphone yang bisa terkoneksi dengan jaringan internet serta dilengkapi oleh aplikasi yang mendukung seperti Whatsapp, Messenger, Instagram, Facebook, dan masih banyak lainnya. Kehadiran internet sangat banyak membatu manusia baik dalam menjaga atau memperpanjang silaturahmi maupun kecepatan dalam memperoleh informasi.

Segala kelebihan pasti memiliki kekurangan juga tentunya. Dengan semua kemudahan yang didapat melalui internet orang-orang mulai menyepelekan segalanya. Contohnya, seperti permintaan maaf yang seharusnya mempertemukan kedua belah pihak yang berselisih, lalu menjelasakan kesalahpahaman, bersalaman dan berbaikan. Sekarang tidak jarang orang meminta maaf melalui status, menulis caption, mengunggah cerita-cerita di media sosial yang ia miliki. Dewasa ini hal itu sangat lumrah, sehingga rasanya orang berbuat kesalahan menjadi begitu mudah, karena meminta maaf tidak pernah susah.

Dari berbagai media sosial yang ada Instagram menjadi aplikasi yang paling populer akhir-akhir ini, apalagi untuk kaula muda. Facebook mulai ditinggalkan karena kurang menarik, dan terlalu banyak iklan. Penelitian ini membahas tentang diksi yang digunakan oleh mahasiswa Pendidikan Bahasa dan Sastra Indonesia (selanjutnya akan disingkat dengan PBSI) angkatan 2017 kelas 5B, dalam penulisan caption Instagram. Penulisan dalam beriteraksi di dunia digital ini harus sangat diperhatikan tingkat kesantunan dan kesopanannya dalam berbahasa dan hal ini tentunya sangat berkaitan dengan pilihan kata dan diksi apa yang dipakai.

Kamus Besar Bahasa Indonesia menuliskan pengertian diksi adalah pilihan kata yang tepat dan selaras dalam 
penggunaanya untuk mengungkapkan gagasan sehingga diperoleh efek tertentu seperti yang diharapkan (Kamus Besar Bahasa Indonesia, 2007;264). Jadi, seseorang dalam penulisan atau pembicaraan pasti memiliki banyak kosa kata di kepalnya. Sebelum berbicara atapun menulis kita pasti sudah memikirkan kata apa yang pantas untuk digunakan. Orang yang memiliki banyak kosa kata cenderung lebih mudah mengungkapkan gagasan yang ia miliki, daripada mereka yang hanya megandalkan kata-kata itu saja. Dari penggunaan diksi yang ia pakai dapat dapat dilihat bagaimana suasana yang berusaha ia bentuk, hal yang ia ingin komunikasikan bahkan kita bisa menebak suasana hatinya lewat diksi tersebut. Pemilahan, pemilihan, dan penempatan kata ketika seseorang sedang berbahasa itulah yang disebut diksi (Fuad, 2005: 62).

$$
\text { Selanjutnya, Keraf (2010: 24) }
$$
mengemukakan tiga kesimpulan utama mengenai diksi, yaitu; 1. Pilihan kata atau diksi mencangkup pengertian kata-kata mana yang dipakai untuk menyampaikan suatu gagasan, bagaimana membentuk pengelompokan katakata yang tepat atau menggunakan ungkapanungkapan yang tepat, dan gaya mana yang paling baik digunakan dalam suatu situasi. 2. Pilihan kata atau diksi adalah kemampuan membedakan secara tepat nuansa-nuansa makna dari gagasan yang ingin disampaikan, dan kemampuan untuk menemukan bentuk yang sesuai (cocok) dengan situasi dan nilai rasa yang dimiliki kelompok masyarakat pendengar. 3. Pilihan kata yang tepat dan sesuai hanya dimungkinkan oleh penguasaan sejumlah besar kosa kata atau perbendaharaan kata bahasa itu. sedangkan yang dimaksud perbendeaharaan kata atau kosa kata suatu bahasa adalah keseluruhan kata yang dimiliki oleh sebuah bahasa.

Berdasarkan pendapat tersebut kita dapat menjelaskan bahwa pilihan kata tidak hanya masalah benar atau salah kata itu digunakan, tetapi juga harus mementingkan penerimaan orang lain agar tidak mengubah suasana yang ada. Karena sebuah kata yang tepat untuk menyatakan sesuatu belum tentu diterima orang lain. Hal ini disebabkan karena adanya aturan atau norma-norma yang berlaku di dalam masyarakat. Jadi, pemilihan diksi pun harus cocok dengan situasi dan kondisi serta aturan yang berlaku.

Jenis diksi menurut Putrayasa (2007: 8 ), ada lima pembagian yaitu 1. Pemakaian kata bermakna denotasi dan konotasi, makna denotasi adalah makna kata yang tidak mendapat tambahan rasa sedikitpun atau biasa disebut makna yang sebenarnya. Sebaliknya, makna konotasi memiliki nilai rasa baik positif maupun negatif. (Chaer, 2009: 65). Makna konotasi mengacu pada makna kias atau makna bukan sebenarnya. 2. Pemakaian kata kajian dan populer, kata kajian sulit untuk dipahami oleh masyarakat umumnya, biasanya banyak digunakan dalam penulisan ilmiah. Hanya orang-orang tertentu yang memahami kata tersebut. Sedangkan, kata populer sering diguakan di berbagai lapisan masyarakat. Contohnya kata lipstick lebih populer dibandingkan kata pewarna bibir. 3. Pemakaian jargon, kata percakapan dan slang. Jargon merupakan kata rahasia pada bidang tertentu yang biasanya terdapat pada bidang seni atau kelompok-kelompok tertentu. Seperti pada kata 'klb' adalah singkatan dari kejadian luar biasa istilah yang sering dipakai oleh kementerian kesehatan tidak semua orang mengetahui kepanjangan dari singkatan tersebut. Kata pecakapan adalah kata yang biasa digunakan dalam percakapan. Kata slang merupakan kata non standar yang informal, disusun secara khas dan digunakan pada suatu percakapan seperti pada kata ciyus, lebay, kere, mager, baper, alay dan masih banyak lainnya. (Wilianti, dkk, 2018;290). 4. Pemakaian kata umum dan kata khusus, kedua hal ini dibedakan berdasarkan keluasan cakupan makna sebuah kata. Semakin luas maka ia sifatnya semakin umum, semakin sempit maka sifatnya semakin khusus. 5. Pemakaian kata bersinonim dan berhomofon, kata bersinonim dimaksudkan untuk memperlihatkan kejelasan kalimat penulis atau pembicara dalam komunikasi, sehingga meminimalisir kesalahpahaman.

Salah satu data pendukung yang sangat relevan dengan penelitian ini ialah pernah dilakukan oleh Rifqi Faizah mahasiswi UIN Jakarata, dalam skripsinya tahun 2015 yang berjudul Penggunaan Diksi dalam Media 
Sosial Facebook dan Implikasinya dalam Pembelajaran Bahasa dan Sastra Indonesia di SMA.

Hasil dari penelitian tersebut diperoleh dari penggunaan diksi yang dipakai oleh 85 mahasiswa dan mahasiswi Pendidikan Bahasa dan Sastra Indonesia (PBSI) dalam media sosial Facebook yaitu diperoleh sebanyak 105 data penggunaan diksi. Dari penggunaan diksi (1) Penggunaan Kata Bersinonim dan Berhomofon sebanyak 86 penggunaan diksi, (2) Penggunaan Kata Bermakna Denotasi dan Konotasi sebanyak 41 penggunaan diksi, (3) Penggunaan Kata Umum dan Kata Khusus sebanyak 8 penggunaan diksi, (4) Penggunaan Kata Populer dan Kata Kajian sebanyak 13 penggunaan diksi, (5) Penggunaan Jargon, Kata Percakapan dan Slang sebanyak 52 penggunaan diksi yang digunakan.

\section{METODE}

Penelitian ini bersifat kualitatif dengan menggunakan metode deskriptif. Yaitu, medeskripsikan data-data yang berkaitan dengan pembahasan. Data yang penulis gunakan yaitu caption Instagram mahasiswa dan mahasiswi PBSI angkatan 2017 kelas 5B. Caption itu penulis pilih secara acak, waktu penulisan caption sekitar tahun 2018-2019. Teknik pengumpulan data yang digunakan yaitu teknik dokumentasi untuk memperkuat informasi, lalu teknik pengolahan data yang dilakukan dengan menggunakan metode simak dan teknik catat. Sehingga, analisis datanya dapat berupa laporan. Dari hasil analisis akan ditarik kesimpulan serta gambaran tentang penggunaan diksi yang ada pada caption Instagram mahasiswa dan mahasiswi PBSI angkatan 2017 kelas 5B.

\section{HASIL DAN PEMBAHASAN Deskripsi Data}

Alasan memilih media sosial Instagram karena media sosial tersebut yang paling sering digunakan oleh masyarakat belakangan ini. Facebook dan Twitter tidak populer lagi, mulai ditinggalkan oleh para penggunanya, dan sekarang mereka memilih Instagram. Hal ini bisa disebabkan karena banyaknya fitur baru yang menarik, tidak hanya sekadar mengirim pesan, videocall atau mengubah gambar profil. Tapi, bisa juga mengahasilkan pendapatan.

Tidak jarang pada zaman milenial ini profesisebagai selebgramyangmempromosikan barang dagangan kepada para pengikutnya dan mereka dibayar mahal untuk hal tersebut. Ini merupakan salah satu kelebihan media sosial Instagram, yang tidak bisa dilakukan oleh media sosial lainnya. Maka dari itu orang berlomba-lomba menaikkan jumlah pengikut agar mendapat endorsment lebih banyak.

Diksi atau pilihan kata dapat menghasilkan efek tertentu baik secara lisan ataupun tulisan. Seperti yang telah dibahas pada pendahuluan pemilihan diksi harus memperhatikan suasana yang ada serta normanorma yang berlaku di dalam masyarakat. Dalam media sosial Instagram kita memang tidak bisa bertatap muka secara langsung, namun interaksi virtual yang dilakukan bisa membuka hubungan sosial.

Dengan banyakanya pengguna media sosial Instagram tidak sedikit kita temui orangorang yang melakukan penyelewengan dalam penulisan diksi, seperti kata kamu diubah menjadi lu, u, loe, 1. Ada juga diksi yang dulunya kasar digunakan menjadi sebutan panggilan seperti anjir, bangsat, kampret, tai, dan masih banyak lagi. Bagi beberapa orang menggunakan diksi seperti itu menjadikan ia terlihat lebih gaul, dan trendy. Walupun tidak ada larangan untuk menggunakan diski tersebut tapi sebaiknya nilai kesopan santunan dalam berkomunikasi harus tetap dijaga.

Sebagai mahasiswa dan mahasiswi PBSI seharusnya dapat menjadi cotoh panutan dalam menggunakan diksi yang baik dan benar, Namun kenyataannya masih ada mahasiswa dan mahasiswi PBSI angkatan 2017 kelas 5B terkadang dalam berkomunikasi tidak memakai penggunaan diksi yang baik di media sosial Instagram. Berdasarkan data yang diperoleh dilihat dari pemakaian diksi dalam Instagram maka dari itu penulis meyimak caption Instagram mahasiswa dan mahasiswi PBSI angkatan 2017 kelas 5B sebanyak 32 orang. 


\section{Analisis Data}

Mahasiswi PBSI kelas 5B berinisialDA memakai penggunaan diksi dalam penulisan caption Instagram pada 28 November 2019, sebagai berikut:

\section{"Yang penting hayuk"}

Caption yang ditulis oleh DA menggambarkan suasana hati yang sedang bahagia, bahwa ia bersedia kemanapun asalkan yang lainnya pun setuju. Penggunaan diksi yang digunakan yaitu;

1. Penggunaan Kata Bersinonim dan Berhomofon

Kata hayuk pada caption di atas merupakan sinonim dari ayo, mari.

2. Penggunaan Kata Bermakna Denotasi dan Konotasi

Penggunaan penting hayuk mempunyai makna konotasi yang artinya bersedia mengikuti apapun yang dijalankan atau diperintahkan.

Mahasiswi PBSI kelas 5B berinisial $\mathrm{CH}$ memakai penggunaan diksi dalam penulisan caption Instagram pada 03 September 2019, sebagai berikut:

"Sebelum tragedi kesembur minyak terjadi"

Caption di atas bermaksud untuk megabarkan sesuatu. Dapat dilihat dari kata sebelum, maka dari itu pasti ada sesudah, dan ada kejadian yang menyertainya. Jadi bahwa $\mathrm{CH}$ telah mengalami sesuatu insiden. Penggunaan diksi yaitu;

1. Penggunaan Kata Bersinonim dan Berhomofon

Kata kesembur merupakan sinonim dari terciprat, atau kecipratan.

2. Penggunaan Kata Populer dan Kata Kajian

Tragedi merupakan kata kajian, yang berarti sesuatu peristiwa yang menyedihkan, pun masyarakat masih sangat jarang menggunakan kata tersebut.

3. Penggunaan Kata Umum dan Kata Khusus

Penggunaan kata minyak merupakan kata khusus yang mengacu pada benda cair. (mis: air, susu, sirup, dan lainnya).
Mahasiswi PBSI kelas 5B berinisial AF memakai penggunaan diksi dalam penulisan caption Instagram pada 11 September 2019, sebagai berikut:

\section{"Tempat Nyender"}

Dari caption AF kita dapat menyimpulakan bahwa ia sedang menunjukkan tempat bersandar yang ia merasa sangat nyaman atas hal itu. Penggunaan diksi yaitu;

1. Penggunaan Kata Bersinonim dan Kata Behomofon

Penggunaan kata nyender memiliki sinonim bersandar. Atau tempat ia bertopang karena capainya.

Mahasiswi PBSI kelas 5B berinisial NM memakai penggunaan diksi dalam penulisan caption Instagram pada 16 Juni 2019, sebagai berikut:

"butuh perjuangan sekali untuk mencapai ke sana. Jalanan yang naikturun membuat kaki lelah, pengunjung yang lain pun berkata tak ingin datang lagi ke sana (sama sih hehe). Curug aja diperjuangin, masa kamu ngga? Wkwkw

Pun dengan segala anagan, jangan hanya menjadi cita-cita. Namun realisasikan dengan ikhtiar dan do'a.

Caption yang ditulis oleh NM merupakan pengalamannya ke suatu tempat, bagaimana rasa lelah yang telah ia dapati, dan suasana yang terjadi. Captiom tersebut memiliki lanjutan setelah dipisahkan oleh titik-titik, dan berisi harapan penulis (NM). Penggunaan diksi yang digunakan yaitu;

1. Penggunaan Kata Bersinonim dan Berhomofon

Kata ngga merupakan sinonim dari kata tidak, penolakan atas segala sesuatu yang tidak ingin dilakukan.

2. Penggunaan Kata Bermakna Denotasi dan Konotasi

Sana merupakan kata konotasi yang bermakna curug, lalu kalimat Curug aja diperjuangin, masa kamu ngga? Bermakna konotasi juga yang bermaksud penulis bisa memperjuangkan dirimu. 
3. Penggunaan Kata Populer dan Kata Kajian

Kata realisasikan merupakan kata kajian karena masyarakat juga masih sangat jarang menggunakan kata tersebut.

4. Penggunaan Jargon, Kata Percakapan dan Slang

a. Slang: kata wkwkwkw merupakan suara tawa, ataupun senang atas hal yang lucu atau membahagiakan.

Mahasiswi PBSI kelas 5B berinisial RS memakai penggunaan diksi dalam penulisan caption Instagram pada 03 Maret 2019, sebagai berikut:

"Pingky Wingki"

Ini ditulis oleh RS untuk menyamakan caption yang ia tulis dan foto yang ia unggah. RS pada foto terlihat menggunakan jilbab warna merah muda (pink),

1. Penggunaan Jargon, Kata Percakapan dan Slang

a. Jargon: kata wingki merupakan sebutan untuk salah satu Teletubies, ia berwarna ungu. Pastinya, kata ini hanya dimengerti oleh mereka yang menonton acara televisi kartu Teletubies.

b. Slang: kata pingky merupakan bahasa Inggris (pink), biasanya kata ini digunakan untuk seseorang atau sesuatu yang berwarna merah muda

Mahasiswi PBSI kelas 5B berinisial UY memakai penggunaan diksi dalam penulisan caption Instagram pada 03 Desember 2018 sebagai berikut:

"Barakallah...U: Mba, mba mukanya kaya Bayi.

K: Hahahahh"

Caption UY bahwa "K" merasa senang wajahnya terlihat lebih muda dari umurnya saat ini. Penggunaan diksi yang digunakan yaitu;

1. Penggunaan Kata Bersinonim dan Berhomofon

Kata mba merupakan sapaan, atau panggilan yang sopan untuk seorang perempuan yang lebih tua dari kita (penyapa).
2. Penggunaan Kata Bermakna Denotasi dan Konotasi

Penggunaan diksi mba mukanya kaya bayi memiliki makna konotasi, yang berarti mukanya terlihat lucu, imut, dan menggemaskan layaknya seorang bayi.

Mahasiswa PBSI kelas 5B berinisial AR memakai penggunaan diksi dalam penulisan caption Instagram pada 05 Maret 2018, sebagai berikut:

"Pada inget kaga boy? Hahaha"

Caption yang ditulis oleh AR untuk mengiatkan teman-temannya dengan kenangan mereka alami terlihat pada foto yang ia unggah. Diksi yang digunakan yaitu;

1. Penggunaan Kata Bersinonim dan Berhomofon

Kata inget merupakan sinonim dari kata ingat, lalu kata kaga juga mempunyai sinonim yaitu tidak, kata pada di atas memiliki sinonim yaitu masih.

2. Penggunaan Jargon, Kata Percakapan dan Slang

a. Jargon: kata boy berasal dari bahasa Inggris yang artinya anak lelaki, dan di dalam bahasa percakan ini merupakan sebuah panggilan AR kepada temantemannya. Hanya ia dan temantemannya yang mengetahui kata boy ini siapa saja.

Mahasiswa PBSI kelas 5B berinisial AE memakai penggunaan diksi dalam penulisan caption Instagram pada 20 Maret 2018, sebagai berikut:

"Berjalanlah bersama-sama di sampingku, jangan di depanku, karena jika di depan, kau akan di tinggal \#kelasb"

Caption yang ditulis oleh AE merupakan sebuah candaan yang serius ia utarakan kepada teman-teman yang berfoto dengannya. Penggunaan diksi yang digunakan ialah;

1. Penggunaan Kata Bermakna Denotasi dan Konotasi

Jika di depan, kau akan di tinggal memiliki makna denotasi bahwa jika kamu berniat 
mendahului maka kamu bukan bagian dari tim.

Mahasiswa PBSI kelas 5B berinisial YH memakai penggunaan diksi dalam penulisan caption Instagram pada 29 Agustus 2016, sebagai berikut:

"Upacara di atas awan"

17 Agustus 2016

YH menulis caption berdasarkan pengalaman yang ia dapat. Mungkin ada rasa bangga baginya melakukan upacara tidak dilapangan melainkan di tempat yang baru dan luar biasa, diksi yang digunakan ialah;

1. Penggunaan Kata Bermakna Denotasi dan Konotasi

Di atas awan memiliki makna konotasi yang berarti sedang berada di puncak gunung. Karena ketika mendaki gunung, saat pagi hari awan terlihat berada di bawah.

Mahasiswi PBSI kelas 5B berinisial NF memakai penggunaan diksi dalam penulisan caption Instagram pada 27 Juli 2019, sebagai berikut:

"Jika dia yang dulunya dekat denganmu lalu tiba-tiba menjauh karena datangnya orang baru, udah senyumin aja $(-)$ "

Caption yang ditulis oleh NF merupakan kata-kata semangat untuk dirinya yang sedang bersedih. Lalu penggunaan diksinya yaitu;

1. Penggunaan Kata Bermakna Denotasi dan Konotasi

senyumin aja, kalimat ini memiliki makna konotasi yang berarti harus rela mengikhlaskan apa yang sudah terjadi.

Mahasiswi PBSI kelas 5B berinisial SC memakai penggunaan diksi dalam penulisan caption Instagram pada 01 Oktober 2019, sebagai berikut:

"Es terossss"

Caption SC tersebut menyatakan bahwa ia sering meminum es, penggunaan diksinya ialah;
1. Penggunaan Jargon, Kata Percakapan dan Slang

a. Slang: Kata terossss atau disebut juga dengan terus yang artinya artinya selalu, lanjut.

Mahasiswa PBSI kelas 5B berinisial F memakai penggunaan diksi dalam penulisan caption Instagram pada 25 November 2019 , sebagai berikut:

"Jangan pernah lagi datang ketika aku mulai terbiasa tanpamu." (Jangan Pernah, 2019)"

"Untuk lihat full version, bisa di channel youtube ku ya. Link ada di bio! : )"

Caption di atas menggambarkan suasana hati F sedang resah dan bersedih. Diksi yang digunakan ialah;

1. Penggunaan Kata Bermakna Denotasi dan Konotasi

Ketika aku mulai terbiasa tanpamu kalimat ini memiliki makna denotasi yang berarti aku sedang berusaha melupakanmu.

2. Penggunaan Kata Umum dan Kata Khusus

Penggunaan kata youtube merupakan kata khusus, dan kata umumnya ialah media sosial.

3. Penggunaan Kata Populer dan Kata Kajian

Penggunaan kata link dan bio, merupakan kata kajian. Bagi pengguna media sosial mungkin ini sudah tak asing, tapi masyarakat yang terdiri dari berbagai macam orang dan budaya tentu ini jarang digunakan.

Mahasiswi PBSI kelas 5B berinisial MC memakai penggunaan diksi dalam penulisan caption Instagram pada 24 Desember 2018, sebagai berikut:

"Kalo diliat-liat, kok keliatan yaa."

Caption yang ditulis oleh MC mengutarakan isi pikirannya. Penggunaan diksi yang digunakan ialah;

1. Penggunaan Kata Bersinonim dan Berhomofon

Kata Kalo memiliki sinonim kalau, jika, seandainya. Lalu kata liat-liat memiliki 
sinonim memperhatikan, dan kata keliatan memiliki sinonim terlihat.

2. Penggunaan Jargon, Kata Percakapan dan Slang

a. Slang: kata kok yang artinya bingung atau terheran-heran.

Mahasiswi PBSI kelas 5B berinisial S memakai penggunaan diksi dalam penulisan caption Instagram pada 19 Maret 2018, sebagai berikut:

"Jangan takut terhadap masa depan, jangantakutterhadaphariesok, jangan takut terhadap diskriminasi, jangan takut mendapatkakan kekerasan atau kejahatan apapun dalam kehidupan sehari-hari, jangan takut memilih dalam pemilu, jangan takut berbicara, jangan takut mengungkapkan pikiran dan pendapat. (SBY)"

Caption yang ditulis oleh $\mathrm{S}$ merupakan kata-kata motivasi yang diucapkan oleh SBY. Penggunaan diksi yang digunakan yaitu;

1. Penggunaan Kata Bermakna Denotasi dan Konotasi

Jangan takut terhadap masa depan, kalimat ini memiliki makna denotasi yang berarti dalam mengahadapi permasalahan yang akan datang harus bersikap berani.

2. Penggunaan Jargon, Kata Percakapan dan Slang

a. Jargon: Kata Pemilu yang artinya (Pemilihan Umum) merupakan kata yang dipakai dalam pemilihan kepala pemerintahan.

3. Penggunaan Kata Populer dan Kata Kajian

Kata diskriminasi merupakan kata kajian, kata ini juga sangat jarang digunakan oleh masyarakat.

Mahasiswi PBSI kelas 5B berinisial DA memakai penggunaan diksi dalam penulisan caption Instagram pada 20 Mei 2019, sebagai berikut:

"Pertemuan dan perpisahan memang adat kehidupan, boleh ada janji? Dengan tetap menjaga silahtuhrahmi.."
Caption DA tersebut ia sedang memberikan nasihat. Penggunaan diksi yang digunakan yaitu;

1. Penggunaan Jargon, Kata Percakapan dan Slang

a. Jargon: kata silaturahmi berasal dari bahasa Arab. Gabungan kata Shilah yang artinya menyambung, dan Rahim: penulisng. Menyambung tali persaudaraan sesama keluarga, kerabat, dan teman.

Mahasiswi PBSI kelas 5B berinisial L memakai penggunaan diksi dalam penulisan caption Instagram pada 05 Sepetember 2016, sebagai berikut:

"Terbaiklaah kalian ituиuиuи (-)"

Caption dari L ia merasa bangga pada sekelompok orang. Penggunaan diksi yang digunakan ialah;

1. Penggunaan Kata Bersinonim dan Berhomofon

Kata terbaiklaah memilki sinonim terbaik, hebat, luar biasa.

2. Penggunaan Jargon, Kata Percakapan dan Slang

a. Jargon: Kalian ituuuuu hanya L yang mengetahui maksudnya ditujukan pada siapa dan atas dasar apa.

Mahasiswi PBSI kelas 5B berinisial SWP memakai penggunaan diksi dalam penulisan caption Instagram pada 24 November 2019, sebagai berikut:

"Mau nulis caption panjang tapi bingung mau mulai darimana. Intinya terimakasih semuanya, senenggg sheva bisa jadi bagian dari salah satu pengalaman kalian"

Terlihat dalam caption SWP kebingungan dalam menulis caption atas rasa bahagia yang ia rasakan. Penggunaan diksi yang digunakan ialah;

1. Penggunaan Kata Bersinonim dan Berhomofon

Kata senenggg berarti senang, atau bahagia. Biasanya atas sesuatu pencapaian atau prestasi. Lalu kata nulis memiliki sinonim menulis. 
2. Penggunaan Kata Populer dan Kata Kajian

Kata populer pada caption tersebut ialah: mau, dari, terima kasih.

Mahasiswa PBSI kelas 5B berinisial PDP memakai penggunaan diksi dalam penulisan caption Instagram pada 04 Juni 2019, sebagai berikut:

\section{"Idul Fitri" \\ "Aku menangis, aku menjerit, di dalam batin" \\ Caption yang ditulis oleh PDP} merupakan ungkapan rasa sedih dan senang yang bercampur baur. Penggunaan diksi yang digunakan ialah;

1. Penggunaan Jargon, Kata Percakapan dan Slang

a. Jargon: kata idul fitri merupakan perayaan hari kemenangan bagi umat muslim seluruh dunia. Dilakukan setelah berpuasa lebih kurang 30 hari lamanya.

Mahasiswi PBSI kelas 5B berinisial IH memakai penggunaan diksi dalam penulisan caption Instagram pada 30 Sepetember 2019, sebagai berikut:

"Egois dikit gak apa-apalah"

Caption IH tersebut menggambar rasa kesal, penggunaan diksi yang dipakai ialah;

1. Penggunaan Kata Bersinonim dan Berhomofon

Kata dikit berarti sedikit, lalu kata gak bersinonim dengan kata tidak, bukan.

2. Penggunaan Kata Bermakna Denotasi dan Konotasi

Egois dikit gak apa-apalah, memiliki makna denotasi yang berarti penulis sudah cukup sabar.

Mahasiswi PBSI kelas 5B berinisial NH memakai penggunaan diksi dalam penulisan caption Instagram pada 12 Juni 2019, sebagai berikut:

"Dasar manusia di negara +62 "

$\mathrm{NH}$ dalam captionnya sedang mengungkapkan kekesalannya, penggunaan diksinya ialah;
1. Penggunaan Kata Bermakna Denotasi dan Konotasi

Negara +62 ini memiliki makna konotasi yang berarti negara Indonesia. Hal ini dikarenakan kode nomor telepon Indonesia ialah +62 .

Mahasiswi PBSI kelas 5B berinisial BK memakai penggunaan diksi dalam penulisan caption Instagram pada 27 November 2019, sebagai berikut:

"Akunya cuma modal nekat.. ditemani dua serintil2kuu"

Caption oleh BK menyatakan bahwa ia telah melakukan suatu yang tidak biasa. Penggunaan diksi yang digunakan ialah;

1. Penggunaan Kata Bersinonim dan Berhomofon

Kata Akunya memiliki sinonim yang berarti penulis.

2. Penggunaan Kata Bermakna Denotasi dan Konotasi

Cuma modal nekat kalimat ini memiliki makna denotasi yang artinya kemampuannya kurang.

3. Penggunaan Jargon, Kata Percakapan dan Slang

a. Jargon: kata serintil2kuu merupakan sebutan BK untuk dua temannya. Dan kata srintil hanya diketahui oleh orang yang telah membaca novel Ronggeng Dukuh Paruk.

Mahasiswi PBSI kelas 5B berinisial FN memakai penggunaan diksi dalam penulisan caption Instagram pada 05 Maret 2019, sebagai berikut:

"Mencoba tirus dengan foto miring, tapi sama aja"

Caption FN menunjukkan usaha yang ia buat untuk mendapatkan hasil foto yang maksimal. Penggunaan diksi yang dipakai ialah;

1. Penggunaan Kata Bersinonim dan Berhomofon

Kata miring dalam caption bersinonim dengan sisi kanan atau kiri. Lalu kata aja berarti saja, memiliki sinonim tetap, biasa. 
2. Penggunaan Kata Bermakna Denotasi dan Konotasi

Mencoba tirus dengan foto miring, kalimat ini memiliki makna denotasi penulis berusaha tampil lebih ramping.

3. Penggunaan Kata Populer dan Kata Kajian

Kata aja merupakan kata populer.

Mahasiswi PBSI kelas 5B berinisial MK memakai penggunaan diksi dalam penulisan caption Instagram pada 13 Maret 2018, sebagai berikut:

"Aku selalu senang di sekolah"

MK menuliskan rasa bahagia pada caption Instagramnya. Penggunaan diksi yang dipaki ialah;

1. Penggunaan Kata Bermakna Denotasi dan Konotasi

Aku selalu senang di sekolah, kalimat ini memiliki makna denotasi, bahwa MK bahagia bersama teman di sekolah. Jika biasanya orang sangat sebal dan tidak betah bersekolah. Maka MK merupakan kebalikannya.

Mahasiswa PBSI kelas 5B berinisial $\mathrm{RB}$ memakai penggunaan diksi dalam penulisan caption Instagram pada 20 November 2017, sebagai berikut:

"Apa abang harus cari cicak dulu, biar bisa lengket di hati eneng??"

Caption yang ditulis oleh RB bermaksud untuk menggoda. Penggunaan diksi yang dipakai adalah;

1. Penggunaan Kata Bermakna Denotasi dan Konotasi

Kata cicak merupakan hewan yang bisa lengket pada dinding, dan hal ini memiliki makna konotasi bahwa penulis ingin bisa berada di hatimu.

2. Penggunaan Jargon, Kata Percakapan dan Slang

a. Jargon: kata eneng merupakan panggilan RB pada seseorang, hanya ia yang mengetahui siapa eneng yang dimaksudkan disini.
3. Penggunaan Kata Umum dan Kata Khusus

Kata cicak merupakan kata khusus dari kata umum hewan.

Mahasiswi PBSI kelas 5B berinisial MP memakai penggunaan diksi dalam penulisan caption Instagram pada 29 Sepetember 2019, sebagai berikut:

\section{"Bcn Bgt.}

Bonus foto di akhir."

MP dalam caption sedang mengungkapkan perasaannya yang berbungabunga. Penggunaan diksi yang dipakai adalah;

1. Penggunaan Kata Bersinonim dan Berhomofon

Kata Bgt maksudnya disini ialah banget, memiliki sinonim sangat, berlebihan, lalu kata bonus memiliki sinonim hadiah.

2. Penggunaan Jargon, Kata Percakapan dan Slang

a. Slang: kata $b c n$ maksudnya ialah bucin (budak cinta), yang rela melakukan sesuatu yang kadang kurang rasional terhadap pasangannya. Kata ini menjadi populer beberapa tahun belakangan ini.

Mahasiswi PBSI kelas 5B berinisial AG memakai penggunaan diksi dalam penulisan caption Instagram pada 08 April 2018, sebagai berikut:

\section{"[So]k imut? Emang iyaa ehehe" \\ "Gausah ngehujat netijen" \\ Caption AG terlihat ia sedang memuji} diri sendiri. Penggunaan diksi yang dipakai olehnya adalah;

1. Penggunaan Kata Bersinonim dan Berhomofon

Kata emang berarti memang, lalu kata imut bersinonim dengan kata lucu, selanjutnya kata ngehujat memiliki sinonim cela, gausah berarti tidak perlu.

2. Penggunaan Jargon, Kata Percakapan dan Slang

a. Jargon: Netijen merupakan sebutan bagi akun-akun media sosial yang sering memberikan komentar, bisa itu komentar baik ataupun buruk. Tetatp 
lebih cenderung pada akun dengan komentar negatif.

b. Slang: kata sok artinya ialah tidak tau kapasitas diri.

Mahasiswa PBSI kelas 5B berinisial FW memakai penggunaan diksi dalam penulisan caption Instagram pada 14 Oktober 2016, sebagai berikut:

"Bersama dalam suka maupun duka"

FW menuliskan caption tentang perasaannya yang bahagia. Pengggunaan diksi yang dipakai adalah;

1. Penggunaan Kata Bersinonim dan Berhomofon

Kata suka memiliki sinonin bahagia lalu kata duka memiliki sinonim bersedih

2. Penggunaan Kata Bermakna Denotasi dan Konotasi

Bersama dalam suka maupun duka memiliki makna denotasi tetap selalu mendukung dalam keadaan apapun.

Mahasiswi PBSI kelas 5B berinisial HK memakai penggunaan diksi dalam penulisan caption Instagram pada 14 September 2019, sebagai berikut:

\section{"Mantull"}

Caption HK tersebut merupakan pujian untuk seseorang atau sesuatu. Diksi yang dipakai ialah;

1. Penggunaan Jargon, Kata Percakapan dan Slang

a. Slang: mantul (mantap betul) merupakan kalimat pujian yang artinya hebat, luar biasa, juara, dan bisa digunakan dalam berbagai hal yang menyatakan arti positif.

Mahasiswi PBSI kelas 5B berinisial RN memakai penggunaan diksi dalam penulisan caption Instagram pada 11 Juni 2019, sebagai berikut:

"Menjaga sebelum terluka akan lebih utama daripada mengobati setelah berderai air mata."

Caption RN memperlihatkan harapannya pada masa depan. Penggunaan diksi yang digunakan ialah;
1. Penggunaan Kata Bermakna Denotasi dan Konotasi

Menjaga sebelum terluka akan lebih utama daripada mengobati setelah berderai air mata, kalimat ini memiliki makna denotasi jangan coba-coba jika tidak sanggup akan resikonya.

2. Penggunaan Kata Populer dan Kata Kajian

Kata berderai merupakan kata kajian yang berarti tetesan, bercucuran, ataupun erat dengan kata menangis.

Mahasiswa PBSI kelas 5B berinisial FDF memakai penggunaan diksi dalam penulisan caption Instagram pada 22 Desember 2016, sebagai berikut:

"Mari terus sambung ukwuah antar pelajar, insyaAllah bermanfaat. \#RohisBrebes\#BrebesBerevolusi."

Caption FDF memperlihatkan semangatnya pada harapan masa depan. Diksi yang digunakan ialah;

1. Penggunaan Jargon, Kata Percakapan dan Slang

a. Jargon: kata Ukhwah adalah tali persaudaraan dalam islam, lalu kata insyaAllah pun merupakan kata yang biasa dipakai oleh muslim untuk memenuhi janji. Biasanya kedua kata ini dipakai oleh para ulama, ataupun para santri, dan anak pondok pesantren. Lalu ada rohis sebutan untuk (Rohani Islam) yang terdapat dalam suatu organisasi.

2. Penggunaan Kata Populer dan Kata Kajian

Kata Berevolusi yang artinya perubahan merupakan kata kajian. Kata ini sangat jarang digunakan dalam masyarakat.

Mahasiswi PBSI kelas 5B berinisial FES memakai penggunaan diksi dalam penulisan caption Instagram pada 03 November 2019, sebagai berikut:

"Calon ibu-ibu sosialita CRB, aamiin ya Allah qobul.. :)"

Caption FES menunjukkan cita-cita yang ingin ia gapai, diksi yang digunakan ialah; 
1. Penggunaan Jargon, Kata Percakapan dan Slang

a. Jargon: kata CRB tidak ada yang tau maksudnya, hanya FES yang mengerti kepanjangan singkatan tersebut dan untuk siapa singktan itu diberikan.

b. Slang: Sosialita merupakan orang yang berpengaruh dalam kegiatan sosial masyarakat.

Mahasiswi PBSI kelas 5B berinisial FQZ memakai penggunaan diksi dalam penulisan caption Instagram pada 24 September 2019, sebagai berikut:

“@dpr_ri

- Dewan penipu Rakyat

- Dewan Pengkhianat Rakyat

- Dewan Perwakilan Rampok"

Caption FQZ merupakan sindiran keras pada DPR RI, penggunaan diksi yang dipakai ialah;

1. Penggunaan Kata Bersinonim dan Berhomofon

Kata Rakyat mempunyai sinonim warga, masyarakyat, kata dewan memiliki sinonim majelis, kata rampok memiliki sinonim pencuri, kata penipu sinonimnya ialah pembohong.

2. Penggunaan Kata Bermakna Denotasi dan Konotasi

Dewan penipu Rakyat, memiliki makna denotasi bahwa dewan telah berbohong kepada masyarakat. Dewan Pengkhianat Rakyat memiliki makna denotasi dewan tidak amanah menjalankan tugasnya.

Dewan Perwakilan Rampok memiliki makna denotasi bahwa dewan telah mengambil hak-hak rakyat.

\section{SIMPULAN}

Bedasarkan hasil penelitian penulisan caption Instagram mahasiswa dan mahasiswi PBSI angkatan 2017 kelas 5B sebanyak 32 orang yang telah dianalisis maka kesimpulan yang penulis dapatkan adalah sebagai berikut:

(1) Penggunaan Kata Bermakna Denotasi dan Konotasi sebanyak 17 pemakaian diksi, (2) Penggunaan Kata Populer dan Kata Kajian sebanyak 8 pemakaian diksi, (3) Penggunaan Jargon, Kata Percakapan dan Slang sebanyak 16 pemakaian diksi, (4) Penggunaan Kata Umum dan Kata Khusus sebanyak 3 pemakaian diksi, (5) Penggunaan Kata Bersinonim dan Berhomofon sebanyak 16 pemakaian diksi.

Pemakaian diksi dalam aspek kesopanan dalam berkomunikasi mahasiswa dan mahasiswi PBSI angkatan 2017 kelas 5B cukup baik. terkadang masih ada yang salah dalam penulisan, dan pemilihan kata. tapi, setidaknya sudah ada usaha untuk mencapai yang terbaik dalam menciptakan komunikasi yang sehat di dunia maya.

\section{DAFTAR PUSTAKA}

Chaer, A.. (2009). Pengantar Semantik Bahasa Indonesia. Jakarta: Rineka Cipta..

Depdikbud. Kamus Besar Bahasa Indonesia. (2007). Jakarta: Balai Pustaka,

Fuad, M dkk. (2005). Penggunaan Bahasa Indonesia Laras Ilmiah. Bandar Lampung: Universitas Lampung.

Keraf, G. (2010). Diksi dan Gaya Bahasa. Jakarta: Gramedia Pustaka Utama.

Rifqi, F. (2015). Penggunaan Diksi dalam Media Sosial Facebook dan Implikasinya dalam Pembelajaran Bahasa dan Sastra Indonesia di SMA. Skripsi pada UIN Syarif Hidayatullah Jakarta. Jakarta.

Wilianti, R. dkk. (2018). Analisis Diksi Puisi Wajah Negeri Kita Karya M. Anwar M.H. Jurnal Ilmu Budaya. Universitas Mulawarman. 